\title{
The Effect of Different Laboratory-scale Sample Preparation Methods on the Composition of Sorghum (Sorghum bicolor L.) and Millet (Panicum miliaceum L.) Milling Fractions
}

\author{
Bernadett Langó1,3, Anna Gyöngyvér Fehér¹, Bernadett Zsófia Bicskei¹, Edina Jaksics¹, \\ Renáta Németh¹, Denisse Bender², Stefano D'Amico², Regine Schoenlechner², Sándor Tömösközi1*

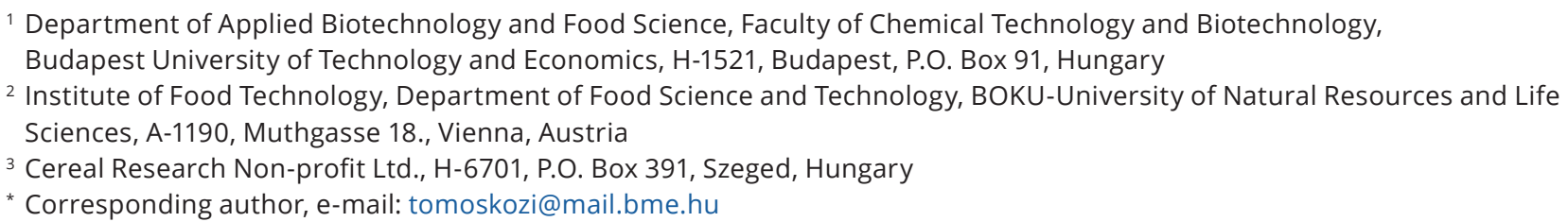

Received: 13 July 2018, Accepted: 08 September 2018, Published online: 11 October 2018

\begin{abstract}
Sorghum and millet are widely used basic food materials in developing countries, but in developed countries their novel food applications were discovered. For their commercial use, no standardized methods are available yet to evaluate their quality as food materials. In this experiment, two different lab-scale procedure (grinding and sieving with or without decortication) were used to obtain flour samples from Hungarian millet and sorghum cultivars and the changes of chemical composition (protein, ash, fat, starch, dietary fiber content) and phytic acid concentration were determined and compared to commercial flours. Both sample processing methods facilitated the separation of the hull, thereby significantly decreased the antinutritive phytic acid concentrations to the same levels as in commercial flours. Decortication increased the flour yield (59-68 \%) of millet, however, in case of sorghum cultivars, no difference in yield (29-35 \%) was detected after decortication. In case of millet cultivars, sieving without decortication decreased the crude protein, fat, ash and dietary fiber concentrations in flour samples to a higher extent, whilst in case of sorghum, sieving after decortication had greater impact on the chemical composition of the flour. However, both millet and sorghum flours showed advantageous nutritional composition compared to wheat flour. In conclusion, for millet sieving supported by decortication was found to be a more efficient sample processing method, but in case of sorghum the effect of decortication was negligible, and the same results were obtained by simple grinding and sieving.
\end{abstract}

Keywords

sorghum, millet, decortication, flour sample preparation, chemical composition, phytic acid

\section{Introduction}

The consumption of millet and sorghum has a great tradition in the developing regions (Africa, East Asia) due to their good adaptation ability to poor agronomical conditions (e.g. unfavorable soil structure, low soil fertility) and different climatic conditions (e.g. low rainfall, drought, high temperature) $[1,2]$. In these areas, these crops are the principal sources of energy, macro- and micro-nutrients [3-5]. Nevertheless, the utilization of these staple cereals for humans has only become more common again in developed countries in the recent years and is expected to rise in the years to come $[6,7]$. Prominently, because of the lack of gluten, they can be consumed in the gluten-free diet but there is a growing recognition also as functional food because of their health-promoting benefits $[8,9]$. The nutritional properties of sorghum and millet flours were reported in several studies, in which these crops were found to be more valuable than other cereals according to their higher content of fat, dietary fiber, antioxidants and the significant amount of essential amino acids, vitamins and minerals $[8,10]$. However, due to the presence of antinutritive compounds (e.g. phytic acid, which has a strong binding affinity to important minerals, such as calcium, iron and zinc) in the pericarp and seed coat, these grains need to be decorticated (removing these parts of the 
seed with mechanical abrasion), and this process affects the nutritional value of the grains $[9,11]$.

In terms of world production, sorghum and millet are in the fifth and sixth place in the order of cereals after wheat, maize, rice and barley with a production of more than 63 and 28 million tonnes in 2016, respectively [12]. In fact, sorghum and millet appellations do refer to a group of different species. One species of sorghum, Sorghum bicolor (Moench) and many of millet Pennisetum glaucum (pearl millet), Eleusine coracana (finger millet), Setaria italic (foxtail millet) and Panicum miliaceum (proso millet) are commonly cultivated. Proso millet is typical in Europe and in Hungary as well [5, 9].

Traditionally, porridge, baked products, extruded products, alcoholic and non-alcoholic beverages are produced from sorghum and millet seeds and from their different types of flours as well as from flour mixtures $[5,13]$. There are Codex Alimentarius (2008) standards for both sorghum and millet grains and also for flour, which are mainly referring to safety issues. Nevertheless, there are no standardized methods of processing food materials and products from sorghum and millet and no coherent methodology has been unified for determining their complex quality [5]. In order to be able to classify and compare samples, the first step is to produce flour samples using a standard method. Earlier studies tested many different methodologies to produce decorticated seeds; e.g. using disk mill after hydrothermal treatment, barley pearler or wooden pestle and mortar [7, 9, 14].

In the present investigation, samples were obtained by equipments generally used in cereal (wheat, rice) qualification. Two different lab-scale milling process, grinding and sieving with or without decortication, were used to obtain flour samples from Hungarian millet and sorghum cultivars. The efficiency and quality of milling were studied; the flour yield was calculated, the chemical composition (protein, ash, fat, starch, dietary fiber content) was determined and also the level of antinutrients were measured by the analysis of phytic acid.

\section{Materials and methods}

\subsection{Plant materials}

Seeds of five proso millet (Panicum miliaceum) and four sorghum (Sorghum bicolor (Moench)) cultivar were investigated from the harvest year 2016. Millet cultivars, GK Alba, GK Piroska, Fertődi-2 and sorghum cultivars, GK Emese, Alföldi-1 were provided by Cereal Research Non-profit Ltd.. Millet cultivars, Maxi and Lovászpatonai pirosmagvú and sorghum cultivars, Albita and Zádor were obtained from University of Debrecen, Research Institute of Karcag. Additionally, commercial wheat (Gyermelyi, Gyermelyi Zrt.), millet (Fűszerház, Füszerház-Vitapharma Kft.) and sorghum (Éden Premium, Naturtrade Hungary Kft.) flour were used as controls.

\subsection{Sample preparation}

From the seeds three types of samples were produced according to Fig. 1: 1.) Seeds were ground and afterwards sieved. The flour fraction $<250 \mu \mathrm{m}$ was collected. 2.) Seeds were first decorticated in 2 steps (dehulling and polishing), then the decorticated seeds were ground and sieved. Flour fraction $<250 \mu \mathrm{m}$ was collected. 3.) Seeds were ground and used as whole meal samples.

Trials were performed to investigate the decortication efficiency at different water adjustment levels, setting the moisture content to $12 \%, 14 \%$ and $18 \%$. The initial moisture content of the grains were between 10 and $11.5 \%$. According to the results, no significant $(P<0.05)$ difference was found in decortication yield (data not shown), therefore moisture content of seeds was adjusted to $12 \%$ according to Hama et al. [7].

The seeds were ground in a METEFÉM FQC-109 Roller Mill (METEFÉM, Hungary). Decortication was carried out applying a two-part process; dehulling and polishing were carried out using PAZ-1 DTA Testing Rice Mill (Zaccaria, Brazil) under constant conditions (sample amount, time, roller distance). For sieving a Vibratory Sieve Shaker AS200 (Retsch, Germany) with sieves $(<250 \mu \mathrm{m})$ were used being compatible with ISO 3310-1:2016. All samples were stored in plastic bags at a temperature of $4{ }^{\circ} \mathrm{C}$ until analysis.

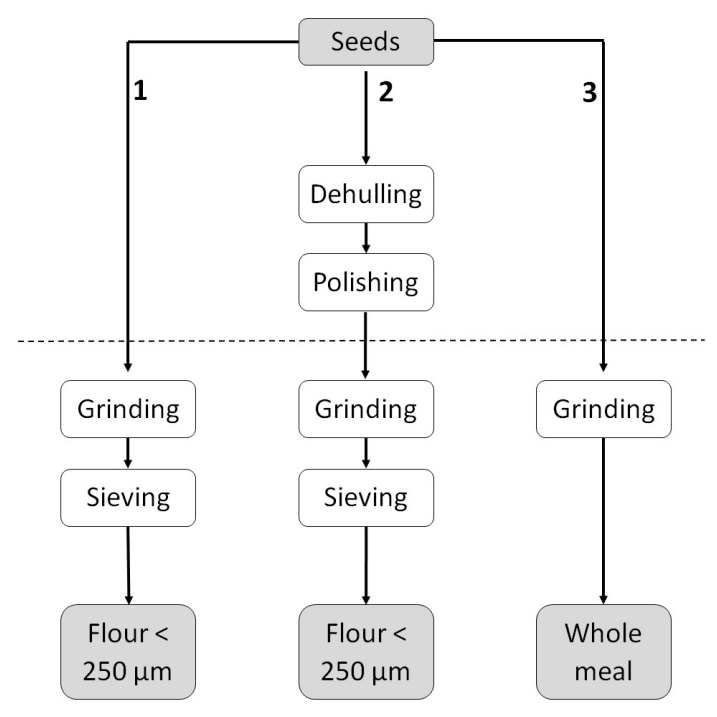

Fig. 1 Experimental design for sample preparation 


\subsection{Analytical methods}

Dry matter content was determined by drying the samples at $135{ }^{\circ} \mathrm{C}$ for $1 \mathrm{~h}$ to constant weight (AACCI 44-19.01). Crude protein content was determined by the Dumas combustion method with the FP-528 Protein / Nitrogen Analyzer (LECO Corporation, USA). Protein concentration was calculated using the formula $\% P=\% N \times C$, where $C$ is 6.25 for cereal grains (AACCI 46-30.01). To determine ash content, we used dry ashing method at $550{ }^{\circ} \mathrm{C}$ (AACCI 08-01.01). Crude fat content was determined by extraction with hexane (AACCI 30-25.01) using Soxtec System HT-145 1043 and 1046 instruments (Tecator, Sweden). Total dietary fiber (TDF) was determined by enzymaticgravimetric method (AACCI 32-07.01) using Fibertec 1023 (Foss-Tecator, Sweden). Phytic acid (phytate) concentration was measured by an enzymatic-photometric method. Both methods applied commercial enzymatic kits (Megazyme International Ireland Ltd., Ireland) [15]. Starch content was estimated by calculating the percent remaining after all the others components have been measured. The samples were analyzed at least in triplicates.

\subsection{Scanning electron micrographs}

To determine original and decorticated seed morphology and their surface details, a scanning electron microscope FEI Inspect S50 (FEI Company Japan Ltd., Japan) at 50X magnification was used.

\subsection{Statistical analysis}

The Statistica 12 software (StatSoft Inc., USA) was used for statistical data analysis. A general linear model (GLM) with significance $(P<0.05$ and 0.01$)$ was used for Analysis of variance (ANOVA). Homogeneity of variances was determined with Hartley-, Cohran-, and Bartlett tests and the difference between means was determined by Post hoc Tukey's HSD test.

\section{Results and discussion}

\subsection{Decortication process}

During decortication, millet and sorghum seeds showed different behavior. Proso millet has a utricle type structure, the seed is covered by the pericarp, which is attached only at one point to the seed $[5,16]$. Therefore, the pericarp was easily and completely removed from the seed, thus dehulling had a strong effect. The polishing effect easily prevailed on the fruit surface and millet seeds were only slightly damaged (Fig. 2 (A)). In case of sorghum, the pericarp is strongly fused to the seed [17], thus only the

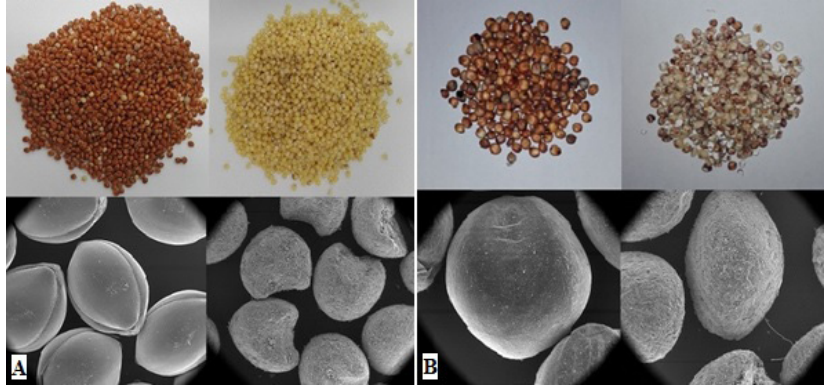

Fig. 2 Pictures and scanning electron micrographs at magnification 50× of original and decorticated millet (A) and sorghum (B) seeds

surface abrasive, polishing effect was effective during the decortication process, resulting in higher grain damage. Hence, the removal of the pericarp was incomplete in sorghum, small pericarp pieces remained on the surface of the decorticated seed (Fig. 2(B)).

\subsection{Milling process}

Flour yield of the different production processes are presented in Fig. 3. For millet, significant differences $(P<0.05)$ were detected between the two process methods in all cultivars, however, cultivar GK Piroska showed the largest difference (15-25\%). In contrast, for sorghum, no difference was found between the flour processing methods. Higher flour yield was obtained in case of millet species. By grinding and sieving, yield ranged from 41 to $48 \%$, while sieving after decortication significantly enhanced the yield to up to 59 to $68 \%$. Regarding sorghum, the flour yield values were similar between both methods (26-35\% for sieving and 29-35\% for decortication supported sieving, respectively). These variations could be attributed also to the differences in grain structure. The higher yields of millet could be achieved due to the easily separable pericarp

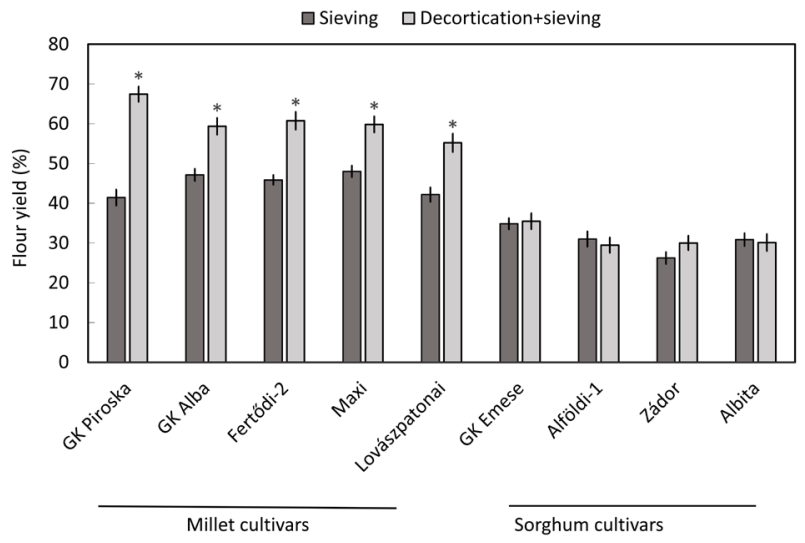

Fig. 3 Flour yield with two different milling processes for millet and sorghum cultivars (cultivars marked with "*" significantly differed at $P<0.05$ ) 
and the smaller particle size as a result of the softer seed structure. Decortication facilitated to separate the hull so increasing the flour yield in millet.

\subsection{Chemical composition}

The chemical composition of the samples is presented in Table 1a and $1 \mathrm{~b}$. The genotypic variance was significant when different millet and sorghum cultivars were compared. The crude protein, crude fat, ash and dietary fiber content were higher in millet than in sorghum whole meal samples. Protein concentration varied from 12.7 to $15.9 \%$ in millet, and 11.8 to $12.7 \%$ in sorghum. Both flour preparation processes decreased the protein content, however in the obtained flour samples they were slightly higher than in the control commercial millet and sorghum flours. In the control wheat flour, the protein content was higher than in the sorghum and millet flours. The crude fat content ranged from $3.87 \%$ to $4.26 \%$ in the whole meal millet samples

Table 1a Crude protein (\%), crude fat (\%) and ash (\%) contents of millet and sorghum cultivars with different sample preparation processes. The contents are on a dry matter basis.

\begin{tabular}{|c|c|c|c|c|c|c|c|c|c|}
\hline & \multicolumn{3}{|c|}{ Crude protein $(\%)$} & \multicolumn{3}{|c|}{ Crude fat $(\%)$} & \multicolumn{3}{|c|}{ Ash (\%) } \\
\hline & WM & $\mathrm{S}$ & $\mathrm{D}+\mathrm{S}$ & WM & $\mathrm{S}$ & $\mathrm{D}+\mathrm{S}$ & WM & $\mathrm{S}$ & $\mathrm{D}+\mathrm{S}$ \\
\hline \multicolumn{10}{|l|}{ Millet } \\
\hline GK Piroska & $12.7 \pm 0.4^{\mathrm{a}}$ & $11.2 \pm 0.3^{\mathrm{a}}$ & $11.6 \pm 0.2^{\mathrm{a}}$ & $3.87 \pm 0.02^{\mathrm{a}}$ & $0.60 \pm 0.09^{\mathrm{a}}$ & $1.28 \pm 0.20^{\mathrm{a}}$ & $2.93 \pm 0.05^{b}$ & $0.42 \pm 0.03^{\mathrm{ab}}$ & $0.61 \pm 0.02^{\mathrm{b}}$ \\
\hline GK Alba & $15.9 \pm 0.3^{\mathrm{c}}$ & $12.1 \pm 0.1^{\mathrm{b}}$ & $14.0 \pm 0.4^{\mathrm{c}}$ & $4.26 \pm 0.11^{\mathrm{a}}$ & $0.55 \pm 0.10^{\mathrm{a}}$ & $1.60 \pm 0.13^{\mathrm{ab}}$ & $2.50 \pm 0.12^{\mathrm{a}}$ & $0.41 \pm 0.01^{\mathrm{ab}}$ & $0.81 \pm 0.05^{\mathrm{c}}$ \\
\hline Fertődi-2 & $13.8 \pm 0.3^{\mathrm{b}}$ & $11.5 \pm 0.2^{\mathrm{ab}}$ & $12.8 \pm 0.1^{\mathrm{b}}$ & $4.10 \pm 0.19^{\mathrm{a}}$ & $1.14 \pm 0.12^{\mathrm{bc}}$ & $1.74 \pm 0.10^{\mathrm{b}}$ & $3.01 \pm 0.08^{\mathrm{b}}$ & $0.40 \pm 0.04^{\mathrm{a}}$ & $0.40 \pm 0.01^{\mathrm{a}}$ \\
\hline Maxi & $15.2 \pm 0.5^{\mathrm{c}}$ & $13.1 \pm 0.3^{c}$ & $14.6 \pm 0.3^{\mathrm{c}}$ & $3.89 \pm 0.24^{\mathrm{a}}$ & $0.87 \pm 0.12^{\mathrm{ab}}$ & $1.26 \pm 0.22^{\mathrm{a}}$ & $2.89 \pm 0.07^{\mathrm{b}}$ & $0.49 \pm 0.02^{\mathrm{bc}}$ & $0.38 \pm 0.04^{\mathrm{a}}$ \\
\hline Lovászpatonai & $13.4 \pm 0.1^{\mathrm{ab}}$ & $11.4 \pm 0.2^{\mathrm{a}}$ & $12.6 \pm 0.1^{\mathrm{b}}$ & $4.10 \pm 0.22^{\mathrm{a}}$ & $1.44 \pm 0.11^{\mathrm{c}}$ & $1.77 \pm 0.14^{\mathrm{b}}$ & $2.93 \pm 0.03^{b}$ & $0.51 \pm 0.04^{\mathrm{c}}$ & $0.55 \pm 0.07^{\mathrm{b}}$ \\
\hline Millet std & & $10.7 \pm 0.4$ & & & $1.97 \pm 0.09$ & & & $0.92 \pm 0.05$ & \\
\hline \multicolumn{10}{|l|}{ Sorghum } \\
\hline GK Emese & $11.9 \pm 0.0^{\mathrm{a}}$ & $10.0 \pm 0.1^{\mathrm{b}}$ & $10.4 \pm 0.2^{\mathrm{b}}$ & $3.25 \pm 0.31^{\mathrm{a}}$ & $1.77 \pm 0.20^{\mathrm{b}}$ & $1.48 \pm 0.10^{\mathrm{a}}$ & $1.18 \pm 0.02^{\mathrm{ab}}$ & $0.64 \pm 0.03^{b}$ & $0.43 \pm 0.02^{\mathrm{ab}}$ \\
\hline Alföldi-1 & $11.8 \pm 0.2^{\mathrm{a}}$ & $10.3 \pm 0.3^{b}$ & $10.4 \pm 0.2^{\mathrm{b}}$ & $3.17 \pm 0.29^{\mathrm{a}}$ & $1.29 \pm 0.14^{\mathrm{a}}$ & $1.16 \pm 0.13^{\mathrm{a}}$ & $1.22 \pm 0.02^{\mathrm{b}}$ & $0.79 \pm 0.03^{c}$ & $0.39 \pm 0.06^{\mathrm{a}}$ \\
\hline Zádor & $12.7 \pm 0.3^{\mathrm{b}}$ & $10.2 \pm 0.1^{\mathrm{b}}$ & $11.2 \pm 0.1^{\mathrm{c}}$ & $3.59 \pm 0.11^{\mathrm{a}}$ & $1.94 \pm 0.19^{\mathrm{bc}}$ & $1.94 \pm 0.22^{\mathrm{b}}$ & $1.02 \pm 0.08^{\mathrm{a}}$ & $0.63 \pm 0.04^{\mathrm{b}}$ & $0.60 \pm 0.04^{\mathrm{c}}$ \\
\hline Albita & $11.8 \pm 0.4^{\mathrm{a}}$ & $8.9 \pm 0.3^{\mathrm{a}}$ & $10.0 \pm 0.2^{\mathrm{a}}$ & $3.70 \pm 0.15^{\mathrm{a}}$ & $2.35 \pm 0.23^{\mathrm{c}}$ & $1.38 \pm 0.17^{\mathrm{a}}$ & $1.07 \pm 0.10^{\mathrm{ab}}$ & $0.58 \pm 0.03^{\mathrm{a}}$ & $0.51 \pm 0.00^{\mathrm{bc}}$ \\
\hline Sorghum std & & $11.2 \pm 0.3$ & & & $2.02 \pm 0.13$ & & & $0.67 \pm 0.04$ & \\
\hline Wheat std & & $15.7 \pm 0.2$ & & & $0.89 \pm 0.08$ & & & $0.46 \pm 0.02$ & \\
\hline
\end{tabular}

Within a column, means with different letters significantly differ at $P<0.05(\mathrm{a}-\mathrm{c}) . \mathrm{WM}=$ whole meal, $\mathrm{S}=$ sieving, $\mathrm{D}+\mathrm{S}=$ decortication and sieving.

Table 1b Total dietary fiber (\%) and starch (\%) contents of millet and sorghum cultivars with different sample preparation processes. The contents are on a dry matter basis.

\begin{tabular}{|c|c|c|c|c|c|c|}
\hline & \multicolumn{3}{|c|}{ Total dietary fiber $(\%)$} & \multicolumn{3}{|c|}{ Starch $(\%)$} \\
\hline & WM & $\mathrm{S}$ & $\mathrm{D}+\mathrm{S}$ & WM & $\mathrm{S}$ & $\mathrm{D}+\mathrm{S}$ \\
\hline \multicolumn{7}{|l|}{ Millet } \\
\hline GK Piroska & $15.8 \pm 0.6^{\mathrm{b}}$ & $5.6 \pm 0.3^{\mathrm{bc}}$ & $5.6 \pm 0.2^{b}$ & $52.1 \pm 0.2^{\mathrm{c}}$ & $69.6 \pm 0.1^{\mathrm{bc}}$ & $67.3 \pm 0.2^{\mathrm{d}}$ \\
\hline GK Alba & $14.2 \pm 0.3^{\mathrm{a}}$ & $4.6 \pm 0.4^{\mathrm{a}}$ & $5.0 \pm 0.2^{\mathrm{a}}$ & $51.9 \pm 0.2^{\mathrm{c}}$ & $71.1 \pm 0.6^{\mathrm{c}}$ & $66.3 \pm 0.4^{\mathrm{c}}$ \\
\hline Fertődi-2 & $17.6 \pm 0.4^{\mathrm{c}}$ & $6.6 \pm 0.2^{\mathrm{cd}}$ & $6.8 \pm 0.1^{\mathrm{c}}$ & $49.8 \pm 0.4^{\mathrm{b}}$ & $68.7 \pm 0.1^{\mathrm{b}}$ & $65.8 \pm 0.1^{\mathrm{bc}}$ \\
\hline Maxi & $16.7 \pm 0.5^{\mathrm{bc}}$ & $4.6 \pm 0.5^{\mathrm{a}}$ & $4.9 \pm 0.3^{\mathrm{a}}$ & $48.9 \pm 0.3^{\mathrm{b}}$ & $69.0 \pm 0.6^{\mathrm{b}}$ & $65.2 \pm 0.3^{\mathrm{b}}$ \\
\hline Lovászpatonai & $19.9 \pm 0.5^{\mathrm{d}}$ & $7.2 \pm 0.7^{\mathrm{d}}$ & $7.6 \pm 0.1^{\mathrm{d}}$ & $46.9 \pm 0.4^{\mathrm{a}}$ & $66.6 \pm 1.0^{\mathrm{a}}$ & $65.5 \pm 0.2^{\mathrm{a}}$ \\
\hline Millet std & \multicolumn{3}{|c|}{$5.23 \pm 0.6$} & \multicolumn{3}{|c|}{$68.7 \pm 0.9$} \\
\hline \multicolumn{7}{|l|}{ Sorghum } \\
\hline GK Emese & $14.5 \pm 0.4^{\mathrm{a}}$ & $10.2 \pm 0.3^{\mathrm{a}}$ & $9.4 \pm 0.0^{\mathrm{a}}$ & $57.2 \pm 0.7^{\mathrm{b}}$ & $65.6 \pm 0.2^{\mathrm{b}}$ & $68.1 \pm 0.1^{\mathrm{c}}$ \\
\hline Alföldi-1 & $13.9 \pm 0.2^{\mathrm{a}}$ & $9.8 \pm 0.1^{\mathrm{a}}$ & $9.4 \pm 0.2^{\mathrm{a}}$ & $57.8 \pm 0.3^{\mathrm{b}}$ & $66.0 \pm 0.3^{\mathrm{b}}$ & $68.0 \pm 0.1^{\mathrm{c}}$ \\
\hline Zádor & $17.4 \pm 0.5^{b}$ & $11.0 \pm 0.4^{\mathrm{b}}$ & $11.2 \pm 0.1^{\mathrm{c}}$ & $52.9 \pm 0.8^{\mathrm{a}}$ & $64.1 \pm 0.7^{\mathrm{a}}$ & $62.7 \pm 0.1^{\mathrm{a}}$ \\
\hline Albita & $13.8 \pm 0.6^{\mathrm{a}}$ & $9.6 \pm 0.3^{\mathrm{a}}$ & $9.9 \pm 0.0^{\mathrm{b}}$ & $57.1 \pm 0.1^{\mathrm{b}}$ & $66.1 \pm 0.8^{\mathrm{b}}$ & $65.9 \pm 0.0^{\mathrm{b}}$ \\
\hline Sorghum std & & $10.6 \pm 0.3$ & & & $63.4 \pm 0.6$ & \\
\hline Wheat std & & $4.5 \pm 0.4$ & & & $66.5 \pm 0.5$ & \\
\hline
\end{tabular}

Within a column, means with different letters significantly differ at $P<0.05$ (a-d). WM $=$ whole meal, $\mathrm{S}=$ sieving, $\mathrm{D}+\mathrm{S}=$ decortication and sieving 
and the ash content ranged between 2.50 and $3.01 \%$. The amount of both components decreased during sample preparation and reached lower values than the control millet flour. In sorghum, the crude fat content was 3.17$3.70 \%$ and the ash content was $1.02-1.22 \%$ in the whole meal samples. Also these values decreased in the obtained flour samples, however it was less evident in sorghum compared to millet. Crude fat and ash contents of the millet and sorghum flour samples with both sample preparation processes were higher than in the control wheat flour. In millet, the total dietary fiber content was 14.2-19.9\% and in sorghum, 13.8-17.4\%. Both of the sample preparation processes negatively affected the dietary fiber levels, the decrease was higher in millet, because the whole pericarp was removed. Also, in the flour samples, sorghum cultivars had higher fiber content, than millet, because of the remaining pericarp. Starch content was lower in whole meal millet flour (46.9-52.1\%) than in whole meal sorghum flour (52.9-57.8\%). As a result of both flour preparation processes, the highest volume of dry mass was presented as starch, 66.6-71.1\% in millet and 62.7-68.1\% in sorghum.

It can be concluded that in millet, already sieving alone decreased the crude protein, fat, ash and dietary fiber concentrations during the flour preparation process, in contrast to sorghum cultivars, in where only sieving followed by decortication decreased the chemical components in the flour.

\subsection{Phytic acid concentration}

Phytic acid concentration varied around $1 \%$ in the whole meal millet samples and from 0.69 to $0.83 \%$ in the whole meal sorghum samples (Fig. 4). Hama et al. [7] found that pearl millet cultivars had lower phytate content, whereas sorghum showed similar phytate values like our samples. Both sample preparation processes decreased phytic acid concentrations, as both the pericarp (bran) and the germ were removed [18]. In the flour samples, the phytic acid concentrations were significantly lower than wholemeal samples, and the genotypic variance was significant $(P$ $<0.05)$. The phytic acid concentrations in millet flours without decortication were significantly higher than in the commercial millet flour, but with decortication the phytic acid concentration was found to be lower than the control millet, except for cultivar Lovászpatonai. Among sorghum flours, in case of cultivar GK Emese and Alföldi-1 there was a significant difference between the two sample preparation methods, while the other two cultivars, Albita

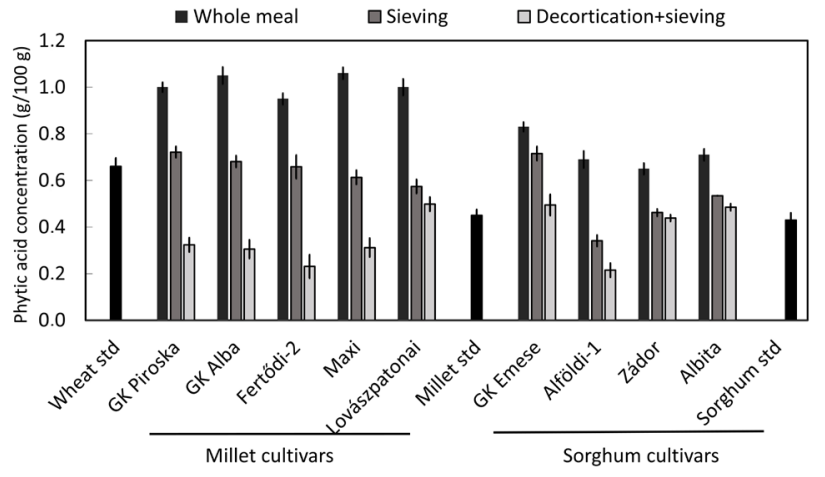

Fig. 4 Phytic acid concentration in millet and sorghum cultivars in whole meal samples and after different milling processes

and Zádor showed same phytic acid concentration like the control sorghum flour.

\section{Conclusions}

The used sample preparation methods seemed to be suitable to produce millet and sorghum flour samples with the same nutritional quality as commercial flours under laboratory conditions. Phytic acid is a good indicator of antinutrients located in the bran and aleurone, and both processing methods decreased the phytic acid concentration in flour samples. Thus these methods could be used as standard sample preparation processes. In case of millet decortication followed by grinding and sieving is the most efficient sample processing method. But in case of sorghum, the effect of decortication was negligible, the same results could be reached with simple grinding and sieving.

It can be concluded, that both millet and sorghum flour have advantageous nutritional properties (higher dietary fiber, lipid, ash content) compared to wheat flour. The genotypic differences draw attention to the need of the examining different cultivars and also provides an opportunity to select more valuable genotypes for novel food production.

\section{Acknowledgement}

This work was supported by the Austrian Scientific Research Fund (FWF) (project I1842-N28) and the Hungarian Scientific Research Fund (OTKA) (ANN-114554), as well as the bilateral Austrian-Hungarian Joint Research Project titled "Fundamental study on the structure, rheological and functional properties of model gluten-free dough and products based on modified carbohydrate systems" (HU 10/2016; TÉT_15-1-2016-0066). This work is also connected to the scientific goals of the BME-Biotechnology FIKP grant of EMMI (BME FIKP-BIO). 


\section{References}

[1] Léder, I. "Sorghum and millets, in Cultivated Plants, Primarily as Food Sources", In: Füleky, Gy. (ed.) Encyclopedia of Life Support Systems (EOLSS), Developed under the Auspices of the UNESCO, Eolss Publishers, Oxford, UK, 2004.

[2] Amadou, I., Gounga, M. E., Le, G.-W. "Millets: Nutritional composition, some health benefits and processing - A Review", Emirates Journal of Food and Agriculture, 25(7), pp. 501-508, 2013. https://doi.org/10.9755/ejfa.v25i7.12045

[3] Food and Agriculture Organization, FAO. "Sorghum and Millets in human nutrition", FAO Food and Nutrition Series, No. 27, Rome, Italy, 1995.

[4] Cardoso, L. M., Pinheiro, S. S., Martino, H. S. D., PinheiroSant'Ana, H. M. "Sorghum (Sorghum bicolor L.): Nutrients, bioactive compounds, and potential impact on human health", Critical Reviews in Food Science and Nutrition, 57(2), pp. 372-390, 2017. https://doi.org/10.1080/10408398.2014.887057

[5] Taylor, J. R. N., Duodu, K. G. "Sorghum and Millets: Grain-Quality Characteristics and Management of Quality Requirements", In: Wrigley, C., Batey, I., Miskelly, D. (eds.) Cereal Grains Assessing and Managing Quality, 2nd ed., Woodhead Publishing, Great Abington, UK, 2017, pp. 317-351.

[6] Rooney, L. W., Waniska, R. D. "Sorghum food and industrial utilization", In: Smith, C. W., Frederiksen, R. A. (eds.) Sorghum: Origin, History, Technology and Production, John Wiley \& Sons, Hoboken, USA, 2000, pp. 689-725.

[7] Hama, F., Icard-Vernière, C., Guyot, J.-P., Picq, C., Diawara, B., Mouquet-Rivier, C. "Changes in micro- and macronutrient composition of pearl millet and white sorghum during in field versus laboratory decortication", Journal of Cereal Science, 54(3), pp. 425-433, 2011.

https://doi.org/10.1016/j.jcs.2011.08.007

[8] Taylor, J. R. N., Schober, T. J., Bean, S. R. "Novel food and nonfood uses for sorghum and millets", Journal of Cereal Science, 44(3), pp. 252-271, 2006.

https://doi.org/10.1016/j.jcs.2006.06.009

[9] Bagdi, A., Balázs, G., Schmidt, J., Szatmári, M., Schoenlechner, R., Berghofer, E., Tömösközi, S. "Protein characterization and nutrient composition of Hungarian proso millet varieties and the effect of decortication", Acta Alimetaria, 40(1), pp. 128-141, 2011. https://doi.org/10.1556/AAlim.40.2011.1.15
[10] Serna-Salvidar, S., Rooney, L. W. "Structure and Chemistry of Sorghum and Millets", In: Dendy, D. A. V. (ed.) Sorghum and Millets: Chemistry and Technology. American Association of Cereal Chemists, St. Paul, USA, 1995, pp. 69-124.

[11] Doherty, C., Faubion, J. M., Rooney, L. W. "Semiautomated determination of phytate in sorghum and sorghum products", Cereal Chemistry, 59, pp. 373-377, 1982.

[12] Food and Agriculture Organization of the United Nations "FAOSTAT, 2016.", [online] Available at: http:/www.fao.org/ faostat/en/\#data/QC [Accessed: 20 June 2018]

[13] Schoenlechner, R., Szatmari, M., Bagdi, A., Tömösközi, S. "Optimisation of bread quality produced from wheat and proso millet (Panicum miliaceum L.) by adding emulsifiers, transglutaminase and xylanase", LWT-Food Science and Technology, 51(1), pp. 361-366, 2013. https://doi.org/10.1016/j.lwt.2012.10.020

[14] Shobana, S., Malleshi, N. G. "Preparation and functional properties of decorticated finger millet (Eleusine coracana)", Journal of Food Engineering, 79(2), pp. 529-538, 2007. https://doi.org/10.1016/j.jfoodeng.2006.01.076

[15] AACC International. "Approved Methods of Analysis", Methods 08-01.01, 30-25.01, 32-07.01, 44-19.01, 46-30.01, [online] Available at: http://methods.aaccnet.org/toc.aspx [Accessed: 20 June 2018]

[16] Dykes, L., Rooney, L. W. "Sorghum and millet phenols and antioxidants", Journal of Cereal Science, 44(3), pp. 236-251, 2006. https://doi.org/10.1016/j.jcs.2006.06.007

[17] Waniska, R. D., Rooney, L. W., McDonough, C. M. "SorghumUtilization", In: Wrigley, C. (ed.) Encyclopedia of Grain Science, Academic Press, Cambridge, UK, 2014, pp. 126-136.

[18] Simwenba, C. G., Hoseney, R. C., Varrino-Marston, E., Zeleznak, K. "Certain B vitamin and phytic acid contents of pearl millet (Pennissetum americanum (L.) Leeke)", Journal of Agricultural and Food Chemistry, 32(1), pp. 31-34, 1984. https://doi.org/10.1021/jf00121a008 